\title{
Triage Approaches Send Adverse Political Signals for Conservation
}

\author{
Ralf C. Buckley* \\ School of Environment, Griffith University, Gold Coast, QLD, Australia
}

Conservation can be analyzed as a political game between advocates and opponents, and games include signals. Triage approaches aim to trade off conservation gains and losses for different species, populations and sites, in an attempt to reduce aggregate net losses. These approaches send a political signal that some local or global species extinctions are socially acceptable. This permits conservation opponents to argue that any species may become extinct where convenient to development interests. Endorsement of triage by any one conservation advocate undermines the efforts and strategies of other conservation advocates. This increases expected aggregate net conservation losses.

Keywords: conservation policy, corporation, landscape, rights, trade-off, economic

\section{OPEN ACCESS}

Edited by:

Matt W. Hayward,

Bangor University, UK

Reviewed by:

Richard Patrick Reading

Denver Zoological Foundation, USA

David Jachowski,

Clemson University, USA

${ }^{*}$ Correspondence:

Ralf C. Buckley

r.buckley@griffith.edu.au; ralf.c.buckley@gmail.com

Specialty section:

This article was submitted to Conservation,

a section of the journal

Frontiers in Ecology and Evolution

Received: 10 December 2015 Accepted: 01 April 2016 Published: 19 April 2016

Citation:

Buckley RC (2016) Triage Approaches Send Adverse Political Signals for Conservation. Front. Ecol. Evol. 4:39. doi: 10.3389/fevo.2016.00039

\section{INTRODUCTION: GAME THEORY APPROACHES TO CONSERVATION POLICY}

The aims of biodiversity conservation relate to other species, but the practice of conservation is a human sociopolitical process (Clark et al., 2015; Redford et al., 2015) which can be analyzed using game theory (Simon et al., 1950), as for other politically controversial environmental measures (Buckley, 2013a). Games include signals, either deliberate or inadvertent, accurate or deceptive (Denicolo, 2008; McCain, 2010). The game is played between advocates who consider conservation a high priority, and opponents who do not (Buckley, 2015). Some opponents are declared and explicit, e.g., regarding livestock predators. Many more are undeclared and implicit, interested in economic gain or material consumption irrespective of environmental impacts. Some advocates endorse intrinsic values, pursue outsider politics, and reject compromise. Others endorse instrumental values, pursue insider politics, and accept compromise. Advocate may adopt positions anywhere on this spectrum.

In any game, successful players need power and strategy. Political power is gained either through force, funds or votes, with variable exchange rates. Conservation advocates rely on votes to change policies and legislation. They aim to enlist popular support in marginal electorates, or appeal to politicians who hold a balance of power. To enlist supporters, conservation advocates appeal to either intrinsic or instrumental interests. Intrinsic-value appeals yield "warmglow" payback, immediate but restricted (Martín-López et al., 2007). Instrumental-value appeals provide broader but delayed and uncertain payback.

Conservation practice is driven and constrained by legislation, derived from past politics. Countries with different legislation have implicitly adopted different positions. Strict protection reflects intrinsic values, derived from culture or religion (Haynes, 2008; Smidt et al., 2009; Norris and Inglehart, 2011). Conditional protection, e.g., through trade-offs or offsets, reflect instrumentalist approaches. Different approaches may be either more or less effective under different conditions. 
There are shifting alliances between players, and subsidiary games within coalitions. Mining interests, manufacturers of motorized recreational vehicles, and a horseriding association combined to oppose roadless-areas legislation in the USA (Havlick, 2002; McBeth et al., 2007; Wolke, 2007). In November 2015, a US-based hunting organization apparently held closeddoor talks with the South African Government to oppose conservation through CITES (Africa Geographic, 2015).

Conservation advocates also form coalitions, with differentiated political positions to attract complementary supporters. If conservation advocates adopt conflicting strategies, however, the political split can be exploited by conservation opponents. One strategy for conservation opponents is to engineer such a split deliberately. Persuading one well-regarded advocate to oppose the majority sends a political signal of doubt and confusion. This is the strategy used by climate-change denialists, and opponents of many science-based policy measures (Beder, 2002).

If any conservation analysts and advocates endorse triage, that creates political signals that damage the effectiveness of other conservation organizations. Advocating triage reduces future resources for conservation, and this outweighs any gains from efficient allocation of current resources. I examine this process for triage of species, subpopulations, and sites.

\section{TRIAGE OF SPECIES}

Triage of species means abandoning some to extinction, and allocating resources to those where extinction can be averted most cheaply. This contrasts with the approach adopted under most threatened-species legislation, which invests most on species closest to extinction, even if this is costly and sometimes fails.

Triage of species suffers from both technical and political shortcomings. There is no scientific threshold to abandon a species to inevitable extinction. With active conservation, some species have recovered from very small remnant populations (Jachowski and Kesler, 2008) or a single breeding pair (Jones et al., 1995). Some have survived in the wild for many decades, at very low numbers, after being believed extinct (Meijaard and Nijman, 2014). Species may be rescuable from a single individual, or even a dead specimen (Minteer, 2014). There is thus no scientific rationale to abandon any species as irremediably doomed. Doom derives less from the genetics of small populations, and more from economics and continuing anthropogenic threats. These are powerful real-world political constraints (Game et al., 2013; Doak et al., 2014), but not impossibilities.

The political shortcoming is that acceptance of triage by any one conservation advocate sends a powerful signal that modifies the entire political playing field. The current global social norm is that all species are invaluable, and any extinction is a loss to all humanity. The current political norm is that extinctions are highly abnormal and regrettable events, that sometimes occur despite our best efforts to avoid them. These norms are embodied in government policy and legislation, agency mandates and budgets, and in the practical politics of social license. Countries which have legislation and associated litigation mandating protection of threatened species, send a strong political signal that development or land use change likely to lead to species extinction will be difficult and expensive to achieve. This influences how industry groups, with no interest in conservation, decide what developments to pursue. If such protection is conditional, through trade-offs or offsets, this signal is far weaker, since it is much easier to influence politicians than to overcome definitively worded legislation (Buckley, 1991a).

Opponents of conservation do not currently possess a social license to declare that extinctions are unimportant. They argue only that in limited local circumstances, other social benefits may outweigh impacts on particular populations of threatened species. Livestock graziers generally do not argue that predator species should become extinct. They claim only that they, or government agricultural agencies, should kill individual predators that might attack their livestock (Rust, 2015). Mineral and petroleum developers, and forestry agencies and corporations, do not claim openly that threatened species are unimportant, because they must comply with legislation and with current social constraints and political norms. They do, however, attempt to change these norms. In consultations for a previous Australian Government's policy papers on sustainable development, for example (Buckley, 1991b) one mining industry representative suggested that in his view, $10 \%$ of Australia's species could become extinct in the interests of mineral production.

Under species-triage approaches, extinctions would be perceived as a normal part of a human-dominated planet. Laws and agencies shift from attempting to avoid any extinctions at all, to choosing between different extinctions on economic grounds (New South Wales, 2014). Species extinctions are treated like business bankruptcies. If the timescales, discount rates and uncertainty measures used in calculating economic paybacks were the same as for commercial investments or government infrastructure, then triage could soon leave us with no other species than those in current commercial use. This political change far outweighs any potential conservation gains through more efficient allocation of current funds under current political systems.

Advocates of species triage argue that some extinctions are unavoidable, and that fixed, limited and fully fungible resources are therefore best allocated where they are most likely to yield the largest conservation benefit. That is, they perceive conservation essentially as an economic optimization problem; and they act as though politics, society, and legislation are a fixed framework, and they are merely tweaking their own operations within that framework. This is incorrect. Advocating triage changes the entire framework. The current conservation view is that extinctions are abnormal anthropogenic events that occur despite conservation efforts, and that conservation efforts should therefore improve. The triage view is that extinctions are normal events within the functioning of a human-dominated planet: a very different position. If it is seen as acceptable to conservationists that one species should become extinct, that signals that it is equally acceptable 
for other species to become extinct (Jachowski and Kesler, 2008). This jeopardizes the position of other conservation advocates. In purely pragmatic terms, triage is a poor gambit.

\section{TRIAGE OF POPULATIONS}

Many threatened species occur at multiple separate sites. Two terminologies are in use to describe geographically separated groups of individuals. Analyses of population viability and genetics generally refer to site-specific populations, which may or may not experience any genetic linkage, and in aggregate comprise a larger-scale (e.g., global) meta-population. That is, the key consideration is generally the genetic flow between different groups of individuals. Analyses of conservation status based on number of individuals remaining, in contrast, commonly refer to a global population divided into individual subpopulations. The key consideration is commonly the boundary of site-specific conservation management efforts. These two considerations are both important in practical conservation. For convenience, I will refer to geographically distinct groups as populations.

Triage at this scale involves abandoning some groups of individuals to extinction in order to focus resources on conserving other groups within the same species. That is, it aims to conserve some individuals of a threatened species, but not others. Since detailed information on population genetics and conservation threats to individual groups is rarely available, triage approaches at population scale focus on estimated numbers of individuals, geographical locations, and estimated management costs. They argue for concentrating conservation resources on populations which are: larger; nearer the center of the species' range; and cheaper to manage, either for reasons of terrain, biology or politics (New South Wales, 2014).

There are both technical and political objections to this approach. The principal technical objection is that smaller outlying populations may be genetically diverse or distinct from larger subpopulations near the center of a species' range. Without detailed data on population genetics, rarely available in practice, abandoning outlying populations to extinction leads to the risk of losing a larger proportion of a species' overall genetic diversity, than loss of a corresponding number of individuals within a larger and more central population. That is, small outlying populations should be considered more rather than less valuable for conservation. This is indeed the approach taken in most practical conservation efforts, but not in population-triage approaches.

The second technical objection is that, especially for threatened species with few individuals remaining, there is always the risk of catastrophic events devastating particular local populations. Such events may be natural, anthropogenic, or a combination. Examples include: disease outbreaks; fires or floods; legal or illegal habitat clearance or destruction; poaching, hunting or harvesting; or war or other armed conflict. It is because of such risks that practical species conservation programs devote efforts and resources to translocating individuals so as to establish or reestablish breeding populations in multiple areas well separated from each other. There are many such programs currently in place (Rhinos Without Borders, 2015). These are measures to reduce the all-eggs-one-basket risk. Triage of populations, in contrast, increases that risk.

The political objection to population-scale triage is that it legitimizes gradual reductions in species range and number of individuals, which reduces the species' ability to maintain a viable population overall and to recover from any short-term reductions. The current legal, social and political norm is that if a species is threatened, every individual of that species is equally protected from "take or harm" (McDonald and Buckley, 1993). Controversies, e.g., over the consequences of trophy hunting (Buckley, 2014), are about mechanisms, not aims.

Population triage approaches, however, signal that it is legally, socially, and politically acceptable for some of the remaining individuals of a threatened species to be destroyed, as long as others remain in existence. That provides an avenue for commercial interests to take or harm individuals, whether through fisheries bycatch, logging or agriculture, clearance for industrial, infrastructure, mineral or residential development, or any other human activity. Once population triage approaches are adopted, the number of remaining individuals can suffer continual attrition, until there is a viable wild breeding population with sufficient size, range and genetic diversity to resisting external shocks.

\section{TRIAGE OF SITES}

Site-based triage approaches abandon some conservation areas to focus resources on others. Many decision rules are possible, using different measures of biodiversity and land tenure. Information is commonly incomplete, especially when "rapid appraisal" is adopted. Prioritizing areas for future conservation is unavoidable (Bottrill et al., 2008), but that is very different from triage of existing conservation areas.

The key issue relates to the conservation value of land subject to anthropogenic modifications. Areas that are no longer pristine can make significant contributions to conservation: e.g., if they still support threatened species and ecosystems not well conserved elsewhere; or if they can be rehabilitated and restocked; or if they provide corridors linking other areas of high conservation value. For some species, the only remaining populations occur on modified landscapes. So, there are indeed cases where it is valuable to invest in conservation of modified as well as pristine ecosystems (Rappaport et al., 2015). Conservation trusts and NGOs can justifiably devote funds, on occasion, to purchasing private farmland. Conservation advocates can justifiably lobby to convert former farming and forestry lands, or waters used for fisheries, to future conservation reserves.

The risk to conservation occurs when this argument is used instead to lobby for social license to create conservation damage to areas that are still pristine. This lobbying approach is used frequently when economic interests want to use current conservation reserves for development, or infrastructure, or large-scale tourism. These interests argue that whilst their actions would indeed create impacts, the land would still be valuable for conservation, just like anthropogenically modified lands elsewhere. This is also the basis for biodiversity offset approaches. The relationship between physical modification to the natural environment and loss in biodiversity conservation value, 
however, is non-linear. Initial damage to pristine ecosystems is rapid and large, whereas recovery of modified ecosystems is slow and limited, a hysteresis effect (Buckley, 1982).

These relationships also differ greatly between ecosystems and types of anthropogenic modification. Grasslands used for low-intensity livestock grazing can be rehabilitated and restocked as conservation reserves for native herbivores and their predators (Varty and Buchanan, 2000; Lewa Wildlife Conservancy, 2015). Cutting roads or power lines through rainforest reserves, in contrast, causes fragmentation of the forest canopy, introduction of invasive species and pathogens, and access by high-impact human recreationists. Politicians, however, have wrongly attempted to argue from grassland to rainforest (Buckley, 2013b).

Landscapes differ by orders of magnitude in human modification. Where human modification is minimal, conservation aims to keep areas pristine. Park managers confine human modification to front-country areas so as to maintain pristine backcountry. Other factors equal, minimally modified lands have higher conservation value than heavily modified lands. The political signal from triage of conservation sites, however, is that if human-modified landscapes are valuable for conservation, there is no barrier to modifying pristine landscapes. If one conservation advocate argues that all landscapes are already modified, this gives conservation opponents a political license to modify wilderness: as attempted unsuccessfully by the Australian Government in the Tasmanian Wilderness World Heritage Area (International Union for Conservation of Nature (IUCN), 2014).

Similar objections apply to proposals that parks agencies could sell some of the lands under their control and buy larger areas elsewhere (Fuller et al., 2010; Venter et al., 2014). Parks agencies operate with annual recurrent funding from central government treasuries. If they sell land, the revenues earned are appropriated by central treasuries, not allocated to buy new parks. Areas proposed for sale and purchase are in different jurisdictions, with no mechanism to transfer funds between governments. If parks agencies buy and sell land, this changes land prices, reducing the total area purchasable. This effect occurs whenever news of proposed purchases reaches landowners. That is why land consolidators use secret intermediaries to purchase adjacent properties. It is also one reason why parks agencies find it so difficult to create corridors between parks by buying private land. Once they start negotiations, all landowners increase prices. Their lands are more valuable to parks agencies, which need parcels in specific sites, than in the open private market with greater substitutability.

\section{DISCUSSION}

The political-signal argument against triage is a pragmatist rather than a fundamentalist approach. There are parallel moral and ethical arguments against triage (Callicott and Grove-Fanning, 2009; Soulé, 2013; Cafaro and Primack, 2014), but those are different. My argument is that if any one well-regarded conservation organization or analyst endorses triage, that sends
TABLE 1 | Good intentions, adverse signals.

\begin{tabular}{lll}
\hline Triage scale & Triage advocates' intent & Inadvertent political signal \\
\hline Species & Minimize total species extinctions & $\begin{array}{l}\text { Species extinctions no longer a } \\
\text { barrier to commercial } \\
\text { development }\end{array}$ \\
Population & Prioritize effort to larger & $\begin{array}{l}\text { Threatened species legislation } \\
\text { no longer a barrier to commercial } \\
\text { development }\end{array}$ \\
& populations & $\begin{array}{l}\text { Parks open for commercial } \\
\text { Site }\end{array}$ \\
& Prioritize resources to sites with & development \\
\hline
\end{tabular}

a political signal which changes the social norms regarding conservation, greatly increasing the barriers to effective action by other conservation advocates. This effect occurs at all scales of triage: species, populations, and sites.

These signals are inadvertent. Conservation analysts and advocates who endorse triage are no doubt well-intentioned, and believe that their proposals will contribute to conservation by allocating resources more efficiently. That is, they focus on choosing between different potential uses of limited funds provided to protected area agencies through annual government budget allocations.

In doing so, however, they create negative consequences for conservation by weakening the defenses of parks agencies, and non-government conservation advocates, against continual attacks by other interests. Such interests see conservation as an obstacle to commercial profit, and parks as resources available far more cheaply than corresponding private lands. Their actions are restricted by threatened species legislation and agencies, and they campaign continually to weaken both. Triage approaches provide large loopholes that are rapidly exploited by commercial interests, which are always in competition for new opportunities, and always engaged in political maneuvers to gain advantage.

The ways which triage approaches are perceived by their advocates are thus very different from the ways in which they are perceived by conservation opponents. These contrasts are summarized in Table 1.

Politics is ultimately a subset of animal behavior. It is a term to describe the ways in which humans gain and apply the power to change social structures in line with their own interests and desires. Many animal species form shifting social alliances; many also deceive each other and sometimes fight each other. I argue here that conservation is a political game, and that conservation efforts are unlikely to succeed unless conservation advocates recognize this, and design strategies accordingly. Games involve signals, either accurate or deceptive. I argue here that if any conservation analyst or advocate adopts triage approaches, that endorsement sends political signals that create damaging effects, and that damage far outweighs any gains which may be achieved through more efficient allocation of resources.

\section{AUTHOR CONTRIBUTIONS}

The author confirms being the sole contributor of this work and approved it for publication. 


\section{REFERENCES}

Africa Geographic. (2015). South African Government and US Hunters Plot Future of Wildlife. Available online at: http://www.africageographic.com/blog/southafrican-government-us-hunters-plot-future-wildlife

Beder, S. (2002). Global Spin: The Corporate Assault on Environmentalism. Devon: Green Books.

Bottrill, M. C., Joseph, L. N., Carwardine, J., Bode, M., Cook, C., Game, E. T., et al. (2008). Is conservation triage just smart decision making? Trends Ecol. Proc. Natl. Acad. Sci. U.S.A. 23, 649-654. doi: 10.1016/j.tree.2008.07.007

Buckley, R. C. (1982). Environmental sensitivity mapping - what, why and how. Min. Enviro. 4, 151-155.

Buckley, R. C. (1991a). Environmental planning legislation: court backup better than ministerial discretion. Environ. Plan. Law J. 8, 250-257.

Buckley, R. C. (1991b). Ecologically Sustainable Development in the Mining and Petroleum Industries (2vv). Canberra: Department of Prime Minister and Cabinet.

Buckley, R. (2013a). Three reasons for eco-label failure. Nature 500, 151. doi: $10.1038 / 500151 \mathrm{c}$

Buckley, R. C. (2013b). Submission 11, Witness Statement and Responses. Public Hearing, Examination of the Nature Conservation and Other Legislation Amendment Bill (Qld). Brisbane, QLD: Hansard.

Buckley, R. C. (2014). Mixed signals from hunting rare wildlife. Front. Ecol. Enviro. 12, 321-322. doi: 10.1890/14.WB.008

Buckley, R. C. (2015). Grand challenges in conservation. Front. Ecol. Evol. 3:128. doi: $10.3389 /$ fevo.2015.00128

Cafaro, P., and Primack, R. (2014). Species extinction is a great moral wrong. Biol. Cons. 170, 1-2. doi: 10.1016/j.biocon.2013.12.022

Callicott, J. B., and Grove-Fanning, W. (2009). Should endangered species have standing? Toward legal rights for listed species. Soc. Philos. Pol. 26, 317-352. doi: 10.1017/S0265052509090268

Clark, S. G., Hohl, A. M., Picard, C. H., and Thomas, E. (eds.) (2015). Large-Scale Conservation in the Common Interest. Heidelberg: Springer.

Denicolo, V. (2008). A signaling model of environmental overcompliance. J. Econ. Behav. Org. 68, 293-303. doi: 10.1016/j.jebo.2008.04.009

Doak, D. F., Bakker, V. J., Goldstein, B. E., and Hale, B. (2014). What is the future of conservation? Trends Ecol. Evol. 29, 77-81. doi: 10.1016/j.tree.2013.10.013

Fuller, R. A., McDonald-Madden, E., Wilson, K. A., Carwardine, J., Grantham, H. S., Watson, J. E. M., et al. (2010). Replacing underperforming protected areas achieves better conservation outcomes. Nature 466, 365-367. doi: 10.1038 /nature09180

Game, E. T., Kareiva, P., and Possingham, H. P. (2013). Six common mistakes in conservation priority setting. Cons. Biol. 27, 480-485. doi: 10.1111/cobi.12051

Havlick, D. (2002). No Place Distant: Roads and Motorized Recreation on America's Public Lands. Washington, DC: Island Press.

Haynes, J. (ed.). (2008). Routledge Handbook of Religion and Politics. London: Routledge.

International Union for Conservation of Nature (IUCN) (2014). Evaluations of Nominations of Natural and Mixed Properties to the World Heritage List WHC. Addendum 14/38.COM/INF.8B2.ADD to Report for World Heritage Committee, Session 38. Gland: IUCN.

Jachowski, D. S., and Kesler, D. C. (2008). Allowing extinction: should we let species go? Trends Ecol. Evol. 24:180. doi: 10.1016/j.tree.2008.11.006

Jones, C. G., Heck, W., Lewis, R. E., Mungroo, Y., Slade, G., and Cade, T. (1995). The restoration of the Mauritius kestrel Falco punctatus population. Ibis, 137, S173-S180.

Lewa Wildlife Conservancy (2015). Lewa Wildlife Conservancy. Available online at: http://www.lewa.org/
Martín-López, B., Montes, C., and Benayas, J. (2007). The non-economic motives behind the willingness to pay for biodiversity conservation. Biol. Cons. 139, 67-82. doi: 10.1016/j.biocon.2007.06.005

McBeth, M. K., Shanahan, E. A., Arnell, R. J., and Hathaway, P. L. (2007). The intersection of narrative policy analysis and policy change theory. Policy Stud. J. 35, 87-108. doi: 10.1111/j.1541-0072.2007.00208.x

McCain, R. A. (2010). Game Theory. Singapore: World Scientific Publishing Co.

McDonald, J., and Buckley, R. C. (1993). The taking offence and lawful activity defence under the Nature Conservation Act 1992 (Qld): when is habitat disturbance a taking? Environ. Plan. Law. J. 10, 198-204.

Meijaard, E., and Nijman, V. (2014). Secrecy considerations for conserving Lazarus species. Biol. Cons. 175, 21-14. doi: 10.1016/j.biocon.2014.03.021

Minteer, B. (2014). Is it right to reverse extinction? Nature 509, 261. doi: $10.1038 / 509261 \mathrm{a}$

New South Wales (2014). Saving Our Species. Department of Environment and Heritage. Available online at: http://www.environment.nsw.gov.au/ savingourspecies/about.htm

Norris, P., and Inglehart, R. (2011). Sacred and Secular: Religion and Politics Worldwide. Cambridge: University Press.

Rappaport, D. I., Tambosi, L. R., and Metzger, J. P. (2015). A landscape triage approach: combining spatial and temporal dynamics to prioritize restoration and conservation. J. Appl. Ecol. 52, 590-601. doi: 10.1111/1365-2664.12405

Redford, K. H., Huntley, B. J., Roe, D., Hammond, T., Zimsky, M., Lovejoy, T. E., et al. (2015). Mainstreaming biodiversity: conservation for the twenty-first century. Front. Ecol. Evol. 3:137. doi: 10.3389/fevo.2015.00137

Rhinos Without Borders (2015). Rhinos Without Borders. Available online at: http://greatplainsfoundation.com/rhinos/, http://www.andbeyond.com/ conservation-community/care-of-the-wildlife/rhinos-without-borders.htm

Rust, N. (2015). Can stakeholders agree on how to reduce human-carnivore conflict on Namibian livestock farms? A novel Q-methodology and Delphi exercise. Oryx. doi: 10.1017/S0030605315001179. [Epub ahead of print].

Simon, H. A., Radin, M., Lundberg, G. A., and Lasswell, H. D. (1950). The semantics of political science: discussion. Amer. Pol. Sci. Rev. 44, 407-425.

Smidt, C., Kellstedt, L., and Guth, C. (2009). The Oxford Handbook of Religion and Politics. New York, NY: Oxford University Press.

Soulé, M. E. (2013). The "New Conservation". Cons. Biol. 27, 897-899. doi: $10.1111 /$ cobi.12147

Varty, S., and Buchanan, M. (2000). The Return: The Story of Phinda Game Reserve. Johannesburg: Londolozi Publishers.

Venter, O., Fuller, R. A., Segan, D. B., Carwardine, J., Brooks, T., Butchart, S. H., et al. (2014). Targeting global protected area expansion for imperiled biodiversity. PLoS Biol. 12:e1001891. doi: 10.1371/journal.pbio.1001891

Wolke, H. (2007). "A Blue Ribbon for distortion: how an off-road vehicle coalition shills for corporate interests," in Thrillcraft: The Environmental Consequences of Motorized Recreation. Foundation for Deep Ecology, San Francisco, ed G. Wuerthner (LCC) Available online at: http://catdir.loc.gov/catdir/toc/ecip079/2007003654.html

Conflict of Interest Statement: The author declares that the research was conducted in the absence of any commercial or financial relationships that could be construed as a potential conflict of interest.

Copyright (C) 2016 Buckley. This is an open-access article distributed under the terms of the Creative Commons Attribution License (CC BY). The use, distribution or reproduction in other forums is permitted, provided the original author(s) or licensor are credited and that the original publication in this journal is cited, in accordance with accepted academic practice. No use, distribution or reproduction is permitted which does not comply with these terms. 